\title{
Digital Citizenship in Ontario Education: A Concept Analysis
}

\author{
Alexander Davis
}

University of Ottawa

\section{Author Note}

Correspondence concerning this article should be addressed to Alexander Davis, University of Ottawa. Email: adavi146@uottawa.ca

\begin{abstract}
Digital citizenship indicates one's place in digitized society; however academics have not established a cohesive understanding about how digital citizenship is characterized. The Ontario Ministry of Education also does not provide a central conceptualization of digital citizenship and instead encourages Ontario school boards to construct and communicate ideas of digital citizenship. Accordingly, Ontario policymakers, educators, and students use differing understandings of digital citizenship, which ultimately impedes educational initiatives and hinders the overall development of the concept. For this paper, therefore, I inquired as to how Ontario public school boards portray digital citizenship. Using concept analysis, I examined digital citizenship documents from the 10 largest English Ontario public school boards. The results suggest that digital citizenship is predominately characterized by responsible and ethical technology use. I conclude with a discussion about how this representation relates to democratic citizenship more broadly and the implications this may have on youth civic engagement.
\end{abstract}

Keywords: digital citizenship; technologies and education; democracy and education; democratic citizenship; concept analysis 


\section{Digital Citizenship in Ontario Education: A Concept Analysis Introduction}

The near-total integration of digital technology into daily lives changes how students interact with and respond to the world. Recently, Statistics Canada (2018) found that essentially all youth aged 15 to 24 use social networking sites, while $75 \%$ of Canadians aged 15-34 use digital technology to remain updated with current affairs. In addition, digital technology offers youth novel spaces to publicly discuss interests, ideas, and issues (Dahlgren, 2003; 2009), while simultaneously exposing youth to complex algorithmic and surveillance mechanisms (Hintz et al., 2019; Turow, 2015). These developments affect democratic citizenship, as Dahlgren (2009) explained: Democratic citizenship is "concerned with social and cultural patterns, identity, and other dimensions ... [pertaining] to ... suitable civic grooming and socialization in civil society" (p. 98 ). These technological developments have incited the formulation of digital citizenship (Mossberger et al., 2008). However, academic characterizations regarding digital citizenship are largely disjointed (Choi, 2016). This discrepancy amongst scholars to create a cohesive definition of digital citizenship is problematic as it leaves policymakers, educators, and students without clear guidance about how to teach, facilitate, learn, and enact digital citizenship. As digital technology affects "the nature of democratic life" (Middaugh \& Kahne, 2009, p. 194) it is important to assess the concept of digital citizenship as it is conveyed to educators and students.

The Ontario Ministry of Education (OME, 2016) recognizes digital citizenship as an emerging priority and includes the concept in provincial school board initiatives (Curriculum Services Canada, 2017). However, unlike other provinces (see Alberta Education, 2012; and Saskatchewan's document, Couros \& Hildebrandt, 2015), Ontario does not have a central conceptualization of digital citizenship. Such conceptual ambiguity impedes educational initiatives (Jones \& Mitchell, 2016). Moreover, the Ontario government's recent decision requiring secondary school students to take a minimum of four online courses throughout their secondary school enrollment (OME, 2019a), further emphasizes the urgency in understanding digital citizenship in Ontario education. Indeed, the COVID-19 pandemic will further entrench the online learning experiences of Ontario students and reinforce the importance of understanding and articulating a cohesive conception of digital citizenship. Doing so is important according to Mattson and Curran (2017), who explained that while digital citizenship has been in use for over a decade, "and legislation requires schools to foster digital citizens, there is still a looming question: How do educators define a digital citizen, let alone teach one?" (p. 145). This posed question was the motivation for this study. However, as Choi et al. (2018) asserted, researchers cannot understand how educators teach and facilitate digital citizenship without first examining educators' influences. Accordingly, my study examined the following research question: How do Ontario public school boards (OPSB) conceptualize digital citizenship? Using OPSBs as the subject of examination is vital as district school boards are responsible for developing policies that promote and support responsible citizenship (OME, 2018a). My aim in this study is to provide conceptual clarity for digital citizenship within Ontario education and to contribute towards the development of the concept across education systems more broadly.

\section{Literature Review}

Although digital citizenship is frequently espoused as an emerging identity in reference to digital trends and social integration, what it means to be a digital citizen has different connotations depending on who is referencing the term. This is unsurprising as the term "citizenship" alone has multiple meanings with complex historical, political, and social influences (Abowitz \& Harnish, 2006). Also worth noting is that citizenship itself, in the democratic sense, has wide 
implications regarding citizens' roles and responsibilities towards societies (Westheimer \& Kahne, 2004). Furthermore, the technological apparatuses that digital citizens necessarily rely upon and navigate profoundly affect notions of citizenship and civic engagement (Bennett et al., 2009; Kahne et al., 2013). Accordingly, to make sense of these ambiguities and tensions and to inform the results of the study, in the following section, I will examine the scholarship regarding digital citizenship as the responsible use of digital technology, critical digital citizenship, educational research examining digital citizenship, and the relationship between digital technology and civic engagement. While the literature review highlights the scholarship of digital citizenship, it concludes by reviewing the relationship between digital technology and youth civic engagement and shows how digital citizenship educational research ultimately ignores this connection.

\section{Personally Responsible Digital Citizenship}

The theoretical conception of digital citizenship is differentiated by two camps of thought. On the one hand, academics have characterized digital citizenship as an individual's responsible use of digital technology. In fact, digital citizenship was introduced by Ribble et al. (2004) to denote the ethical use of technology. Ribble (2012) subsequently conceptualized digital citizenship in nine components revolving around the safe and responsible use of digital technology. This approach encapsulates the necessary behaviours and actions to use digital technology and is informed by "concerns that are affecting ... schools and students, whether these are technology related or not" (Ribble, 2012, p. 149). The International Society for Technology in Education (2016) also embraced this approach as its grounding framework and much of the available digital citizenship research does so as well. Researchers have referred to Ribble's model as personally responsible digital citizenship (Krutka \& Carpenter, 2017; Mattson \& Curran, 2017) because the implications of technological use are limited to a sense of responsibility to others, technology, and digital communities. This personally responsible model of digital citizenship is used by researchers in developing digital citizenship scales (Isman \& Gungoren, 2014; Kim \& Choi, 2018). Kim and Choi (2018) created a youth digital citizenship scale for adolescents termed the SAFE framework, which comprises of four categories involving digital identity and reputation, positive and safe online behaviour, digital literacy, and ethical online behaviour. However, such conceptualizations exclude the potential of digital technology to be used for democratic processes (i.e., researching social issues, critically navigating various news sources, signing and sharing digital petitions, etc.). Does this limitation therefore insinuate that democratic values and processes are not related to digital citizenship? The following theoretical conception of digital citizenship rejects such an exclusion.

\section{Critical Digital Citizenship}

Advocates of the second theoretical conception, referred as critical digital citizenship (Choi et al., 2017), certainly object to limiting the role of digital citizens to only responsible digital technology use and instead perceive digital citizenship as an extension of democratic citizenship. Similarly, other researchers (Choi et al., 2018; Krutka \& Carpenter, 2017; Mattson \& Curran, 2017) have appropriately explained that digital citizenship must develop beyond personally responsible frameworks and include broader notions of civic agency and community involvement. Although Kim and Choi's (2018) SAFE framework for digital citizenship predominantly addresses safe and responsible digital technology use, the researchers nonetheless have admitted that digital citizenship education should encourage students to interact "with other citizens with various interests in the online community to solve various community and global 
problems" (p. 168). The researchers' perception that digital citizenship should include both responsible use as well as civic engagement aspects aligns with Choi et al.'s (2017) multilayered conception of digital citizenship. They have distinguished the concept according to the four strata of: digital ethics, media and information literacy, participation and engagement, and critical resistance. Interestingly, university students seem to share this understanding as they perceive digital citizenship as comprising of the technical, safe, and responsible use of digital technology, but also recognize digital citizenship as involving political, social, and cultural actions (Kara, 2018).

In considering how digital media reconfigures the ease to produce, distribute, and follow news, Hobbs, et al., (2013) have asserted that digital citizenship education should facilitate literacy skills required for democratic dialogue. Similarly, Gleason and Gillern (2018) examined how digital media applications may encourage citizenship education for middle and secondary school students and demonstrate how community organizations may facilitate civically engaged forms of digital citizenship. The researchers acknowledged that digital citizenship is partly characterized by its normative conception of appropriate technology use; however, they have extended this understanding to facilitate civic agency in youth. They specifically explained that "Digital media offers an engaging way for young people to learn about significant dimensions of citizenship and civic education while lowering barriers to participation" (p. 208). Accordingly, such critical conceptions of digital citizenship recognize the deliberative, democratic capacity of digital technology to motivate youth towards civic engagement.

Using Ritzer and Jurgenson's (2010) idea of the prosumer, McGillivray et al. (2016) developed a theory of critical digital citizenship, whereby critical digital citizens value creating online content while simultaneously being critical of online information consumption. As the researchers explained, critical digital citizens ultimately, "ponder how digitally mediated publics operate, and think carefully about ... ownership, privacy, security, and risk in the school setting and beyond" (p. 736). Indeed, critical digital citizenship prioritizes an evaluative attitude towards online information. This critical approach to navigating information relates to the disciplinary literacy that Wineburg and Reisman (2015) connected to digital citizenship and also correlates to the conception of digital citizenship as envisioned by Choi (2016). That is that digital citizenship "includes abilities, thinking and action regarding Internet use, which allows people to understand, navigate, engage in, and transform self, community, society, and the world" (Choi, 2016, p. 584). Such constructions of digital citizenship impact student information processing, as Kahne and Bowyer (2017) found: Media literacy education positively influenced students' critical acquisition of online information. As opposed to Ribble's (2012) personally responsible digital citizen, the critical digital citizenship relates to democratic citizenship as it considers civic involvement in a community and implications for improving society via digital technology. This conceptualization is concerned with being critical of information during the process of engaging with and navigating the world, and also extends informed and critical perspectives to civic engagement. However, how does educational scholarship approach digital citizenship with regards to these two conceptual paradigms?

\section{Educational Research and Digital Citizenship}

Overwhelmingly, educational research examines digital citizenship within the personally responsible framework. For example, Berman-Dry (2013) encouraged sixth grade students to debate digital technology issues that students their age may encounter, thus demonstrating that digital citizens adequately navigate and avoid risks posed by digital technology. Similarly, in 
examining middle school students' social media use, Martin et al. (2018) emphasized the risks associated with social networking. Consequently, these researchers associate digital citizenship with both the awareness of risks posed by digital technology as well as the appropriate and responsible use of digital technology. In addition, other researchers (Kirkman, 2014; Mesch, 2018; Nebel et al., 2009; Ohler, 2012; Young, 2014 ) understood digital citizenship as responsible use of digital technology and avoidance of associated risks, while Jones and Mitchell (2016) have asserted that digital citizenship must incorporate greater emphasis for respect and tolerance. Emphasizing ethical behaviour, Robb and Shellenbarger (2013) explained that students, as digital citizens, are responsible for maintaining academic integrity while using digital technology to conduct academic research. Similarly, Winn (2012) focused on digital citizenship as digital etiquette and discussed how his PreK-12 school used a school social networking site to facilitate learning, while specifically reinforcing digital citizens as wellbehaved digital technology users. This corresponds with Hollandsworth et al. (2011) who expressed the concern that ignoring the risks of digital technology will perpetuate the negative consequences of digital technology. They explained that digital citizenship should prioritize creating "good citizen[s] in the digital community" (Hollandsworth et al., 2011, p. 38), by specifically considering safety, improving educational experiences, and engaging with proper ethical and legal behaviours. Accordingly, digital citizenship is very much framed according to responsible technology use, respectful behaviour, and being cognizant of the risks associated with digital technology use.

However, James (2014) found that youth perceive such limited digital citizenship approaches to merely perpetuate a fear-driven narrative regarding digital technology use. Indeed, while educational research frames digital citizenship as the appropriate use of digital technology, it does so largely by emphasising the risks of digital technology and of highlighting the consequences of failing to ignore responsible use (i.e., academic integrity). Of course, the responsible use of technology is essential; however, as Choi et al.'s (2017) framework reflects, responsible use of digital technology is one part of a multilayered conception. Instead, educational research excludes the full potential of digital technology to influence democratic practices by ignoring digital citizenship as related to democratic citizenship. Accordingly, if digital citizenship is related to democratic practices, what is the relationship between digital technology youth civic engagement?

\section{Technology and Youth Civic Engagement}

Researchers question the efficacy of traditional civic education (see Bennett et al., 2009; Manning \& Edwards, 2014) and have found that digital technology is reformulating civic identities (Bennett et al., 2009; Coleman, 2013; Couldry et al., 2014). The quick development of new digital technology and social media fundamentally changes how citizens interact and ultimately "lower[s] the threshold for involvement in collective action and, eventually, politics, [which] changes the power dynamics of participation" (Bakardjieva et al., 2012, p. i). In their seminal work on digital citizenship, Mossberger et al. (2008) optimistically associated digital technology with removing the social barriers hindering civic engagement.

Researchers have asserted that the use of digital technology increases youth civic engagement (Fournier-Sylverster, 2013; Kahne et al, 2016; Kahne et al., 2013; Lee et al., 2012) and have argued that this aspect should be incorporated into civic education. Similarly, in their study of the blogger community, Panke and Stephens (2018) found that social media use promotes civic engagement and civic reasoning. Even non-political online activities enable 
political participation. For example, Wojcieszak and Mutz (2009) found that more than half of adults participating in non-political interest-driven online discussion (i.e., sports, hobbies, etc.), expressed and discussed political opinions with one another. Similarly, Kahne et al. (2013) determined that online interest-driven participation positively predicts levels of youth civic engagement. They explained that "different kinds of online participation are associated with different kinds of civic and political activity, such as volunteering, political expression, and voting" (Kahne et al., 2013, p. 11). In fact, online participation influences offline civic engagement (Baumgartner \& Morris, 2010; Kim et al., 2017; Mossberger et al., 2008; Pasek et al., 2009).

However, this raises important questions about the limit of being a digital citizen. For example, when someone shifts from digital technology to physical means of civic engagement, does that individual therefore cease to become a digital citizen? Or does digital citizenship merely refer to democratic citizens navigating and civically engaging via digital spheres, hardware and software? The following section will explain the methodology I used to determine whether Ontario public school boards integrate such considerations and notions into their conceptions of digital citizenship.

\section{Methodology}

\section{Theoretical Framework}

This study understands democratic citizenship as enacted through civic action and considers digital citizenship as similarly requiring elements of civic engagement. This aligns with scholars of both critical digital citizenship and those who perceive a positive relationship between youth technology use and civic engagement. In addressing the type of democratic citizens necessary for supporting an effective democracy, Westheimer and Kahne (2004) developed three conceptions of democratic citizenship: personally responsible citizenship, participatory citizenship, and justice-oriented citizenship. These conceptions characterize types of democratic citizenship; however, each type has differing underlying assumptions about the roles and responsibilities of democratic citizens. For example, the personally responsible citizen obeys established laws and is responsible to their community. The participatory citizen actively participates in society as a way of improving society. Lastly, the justice-oriented citizen critically inquires, assesses, and questions structures in order to solve social problems. Richards (2010) further connects digital citizenship to democratic citizenship through creating pedagogical ideas to model digital citizenship education along with these three conceptions. I therefore employed a democratic theorization of digital citizenship that prioritizes civic agency. Specifically, the results presented here were compared to Westheimer and Kahne's (2004) conceptions of democratic citizenship to understand how OPSBs construct and convey digital citizenship.

\section{Concept Analysis}

This study used a concept analysis to examine how OPSBs conceptualize digital citizenship. Because concepts are unfixed and discursively communicated to create meaning through their use (Toulmin, 1972), analyzing how concepts are communicated, yields an understanding towards further conceptual development (Rodgers, 1989). Choi (2016) also applied this research method to her review of digital citizenship research. Due to the fragmented research on digital citizenship, it is important to understand how school boards conceptualize digital citizenship and communicate the concept to teachers and students. The conceptual ambiguity of digital citizenship impairs educational initiatives (Jones \& Mitchell, 2016); 
however, concept analysis can extrapolate its current meaning in use and further develop the concept (Foley \& Davis, 2017). I used Rodgers' (1989) method of concept analysis and adhered to the following phases of:

- identifying and naming the concept of interest,

- identifying related terms of the concept,

- selecting an appropriate sample for data collection,

- identifying attributes of the concept,

- determining the references and consequences of the concept, and

- identifying concepts related to the concept of interest. (p. 333)

Attributes indicate the meaning of a concept in use (Rodgers, 1989). Accordingly, when examining OPSB digital citizenship documents, I specifically searched for how documents characterized digital citizenship. Data were first open coded to recognize attributes and categorize common themes by using descriptive coding to identify the basic aspects of digital citizenship (Saldaña, 2013). This analysis adhered to descriptive coding as outlined by Linneberg and Korsgaard (2019), who explained that these segments of data are labeled to indicate "the meaning of the segment of data in relation to the overall research topic" (p. 16). Subsequently, axial coding was conducted to establish categories and saturate the data. Axial coding categorized the segments of data as they related to one another, which ultimately sorted the segments into conceptual categories (Charmaz, 2006; Saldaña, 2013). To categorize segments of data, data was inputted and tracked with a tree diagram to determine robust categories. These concepts were ultimately identified and extrapolated upon by comparing categorized themes with Westheimer and Kahne's (2004) types of democratic citizenship.

\section{Sample}

The 10 largest OPSBs were included in this study, determined by the total combined number of elementary and secondary schools in each district. This was calculated through school information and student demographic data provided by the OME (2019b). As a result of selecting this sample by size, all examined OPSBs were English boards. Upon calculating the total board size, the only criteria for inclusion into the research sample was to have a publicly accessible document outlining the school board's perception and description of digital citizenship. Documents were located through searching school board websites. One school board was excluded from the sample because the board did not have an accessible digital citizenship document. The following 10 Ontario public district school boards (DSBs) were selected for data collection: Toronto, Peel, Thames Valley, Ottawa-Carleton, Durham, Waterloo Region, Hamilton-Wentworth, Halton, DSB of Niagara, and Simcoe County. Using data from the 20172018 academic year Ontario Public Schools Enrollment (OME, 2018b), I calculated that students from these 10 OPSBs comprise nearly $64 \%$ of the total Ontario public school student population, and, therefore, a sample of these 10 OPSBs was deemed a robust sample. A list of examined documents are presented in Appendix A.

\section{Results}

In following Rodgers' (1989) steps for concept analysis, I next present the results from examining the surrogate terms of digital citizenship as well as the attributes related to digital 
citizenship. The discussion then addresses the implications of OPSBs' conceptualization as well as elaborating upon digital citizenship as a related concept to democratic citizenship.

\section{Related Terms of Digital Citizenship}

In reviewing academic literature, Choi (2016) found that digital citizenship has the following related terms: online citizenship, cyber citizenship, e-citizenship, networked citizenship, technological citizenship, and Internet citizenship; however, my search of OPSB documents did not correlate with this finding. In fact, no related terms were found. Therefore, I conclude that OPSBs approach is to use the concept specifically as digital citizenship and the common term for exploring the concept is digital citizenship.

\section{Digital Citizenship Attributes}

The analysis yielded the following three major attribute categories constituting digital citizenship: Behavioural, Skills, and Digital Rights. Three other codes were identified; however due to their low consistency and incompatibility with other categories, these codes were not individually categorized. These codes are presented as Other in Figure 1 (see below). These Other codes were: health $(n=4)$, surveillance compliance $(n=1)$, and connection to activism $(n=$ 1). Behavioural attributes were the predominant characterization of digital citizenship, $(n=89)$, while skills attributes were the second most common $(n=12)$, and digital rights $(n=9)$ were the third most common. The total percentage of these categories in relation to each other is presented in Figure 1. The following discusses these attributes and references.

\section{Figure 1}

\section{Attribute Categories of Digital Citizenship}

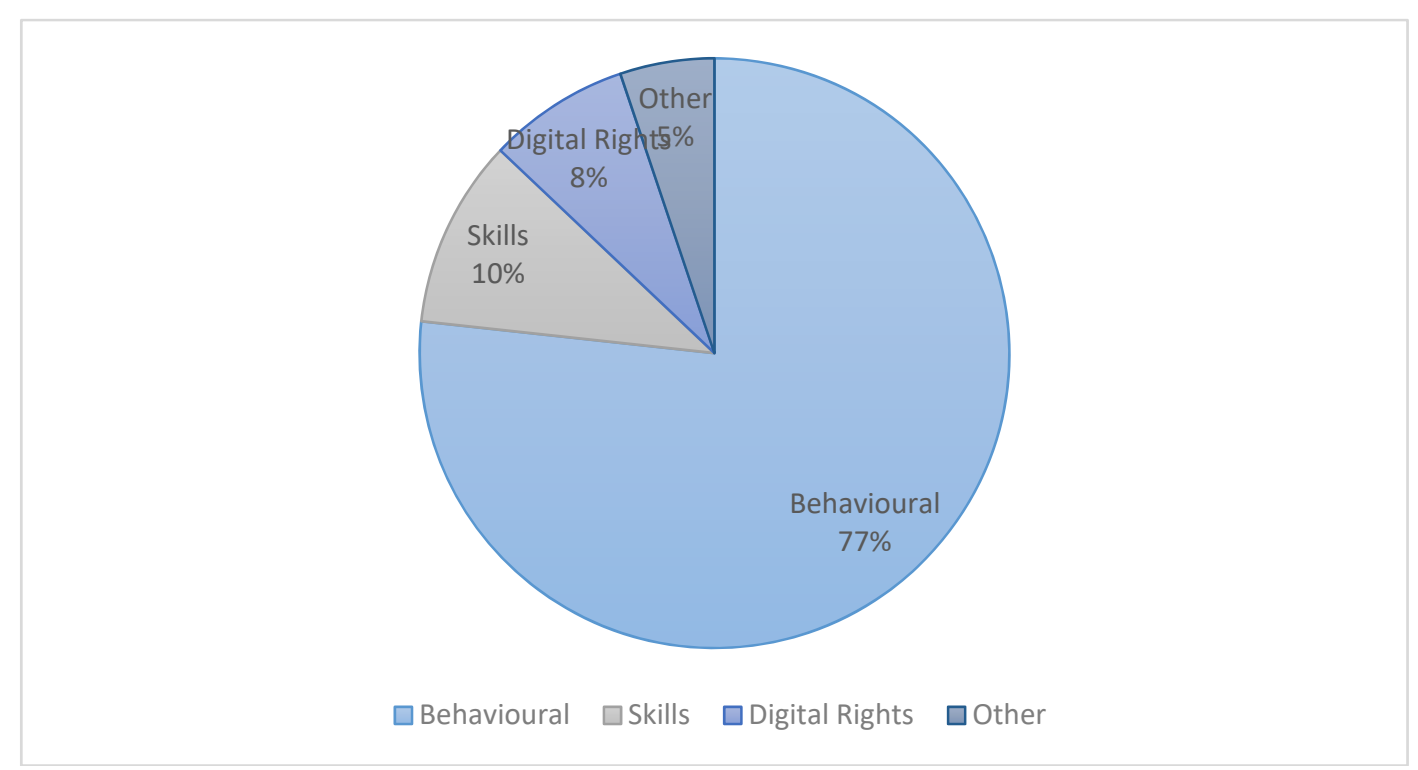

Note. This figure illustrates the four attribute categories composing digital citizenship.

\section{Behaviour Attributes}

The behavioural attribute of digital citizenship ultimately comprises of four subcategories: safe behaviour, responsible behaviour, respectful behaviour, and legal behaviour. Safe behaviour $(n=28)$ involved the recognition that digital technology poses numerous threats which require the need to protect personal privacy, consider cybersecurity, and recognize the 
risks posed by cyberbullies and predators. However, safe behaviour was most often described as emphasizing a need to protect privacy in general terms, emphasizing the awareness of the need to ensure personal data is secure and shared with discretion.

Responsible behaviour $(n=26)$ revolved around the appropriate use of technology. This focused on using digital hardware and software for its intended purpose, balancing online activity with offline activities, being cautious not to overshare on social media, and recognizing that unintended audiences can view user activity. Digital citizenship suggests that the digital citizen is accountable either to oneself or to technology itself. According to this attribute, digital citizens should be particularly cautious about being too public online and representing oneself positively online. Furthermore, the link between school and technology was established by highlighting the use of technology for its intended purposes, and not, as one instance specified, as a distraction to classroom learning. Digital citizenship also required responsible behaviour, using digital technology in a manner that preserves student academic integrity.

Respectful behaviour $(n=22)$ regarded as being respectful towards oneself and others, also included being respectful towards school board technology and reporting instances when school board technology is not properly operating. This also included showing respect to digital devices and respecting others' personal privacy and data. Respectful behaviour also included being tolerant of differing opinions and avoiding and reporting instance of cyberbullying.

Lastly, legal behaviour $(n=13)$ regarded using digital technology within the confines of federal and provincial law, and school board codes of conduct. Digital citizens were expected to understand and not infringe on copyright licensing. Furthermore, digital citizens were also expected to understand that all data was legally owned, stored and could be accessed by the school board.

\section{Skills Attributes}

The skills attribute of digital citizenship included three subcategories: technical skills, critical skills, and academic skills. Technical skills $(n=6)$ pertained to the ability to search for information online and the capability to effectively use digital platforms. Critical skills $(n=5)$ included the literacy skills necessary to understand the strategies that marketers will use to persuade consumers as well as the evaluative skills to determine the validity of online information. This also correlated with having literacy skills to navigate marketing messages. Lastly, academic skills $(n=1)$ involved understanding the proper method of citing online materials. This of course, also aligns with the responsible behaviour to use digital technology in a manner consistent with preserving academic integrity.

\section{Digital Rights Attributes}

Digital rights were specifically described by recognizing that all individuals have the right to access digital technology and basic rights. The right to access $(n=6)$ included student rights to access personal devices and that students have the right to access educational resources while using their personal devices on school board property. Such access was restricted to only using personal devices for educational purposes. Basic rights $(n=3)$ included the right to privacy and the right to freedom of speech. Interestingly, despite basic rights including the right to privacy, one of the Other codes from an OPSB document informed students to accept that all digital technology use on school board property was eligible for administrative monitoring. 


\section{Discussion}

The results are similar to Choi's (2016) review of digital citizenship research in that OPSBs largely describe digital citizenship as responsible and ethical behavioural. OPSBs expect digital citizens, as digital community members and digital technology users, to primarily engage in safe, responsible, respectful, and legal behaviour. Ontario digital citizens are expected to behave appropriately within the confines of established digital etiquette, rules, and laws. Accordingly, OPSBs conceptualize digital citizenship to accord with the personally responsible citizen (Westheimer \& Kahne, 2004) - specifically in how a personally responsible citizen "acts responsibly in his/her community ... [and] ... obeys laws" (p. 240). According to OPSBs' conceptualization of digital citizenship, digital citizens are described as maintaining a safe digital community. However, this conceptualization fundamentally centralizes the role of the individual. Accordingly, such digital citizenship initiatives share the personally responsible citizenship education focus that emphasizes individual acts above collective efforts to address community issues and social justice (Westheimer \& Kahne, 2004). In fact, only one Other code from an OPSB associated digital citizenship with community activism. Therefore, OPSBs mirror the behavioural understanding of digital citizenship as advocated by Ribble $(2012$; 2015), while critical digital citizenship perspectives are predominantly excluded. Such a conceptualization fundamentally ignores the technological influence on youth civic engagement. Instead, digital citizenship is primarily concerned with individual efforts to maintain an established digital social order. These excluded concerns for collective efforts impact the very democratic function of education and the positive role of digital technology influencing civic engagement.

While research demonstrates new understandings of civic culture and civic identity emerging from the integration of digital technologies, OPSBs do not include the civic potential of technology within their conceptualization of digital citizenship. Nor do OPSBs incorporate critical dimensions of digital citizenship. Despite the evidence that youth engage in lifestyle politics (Bennett et al., 2009), engage civically through digital technology use (Kahne et al., 2013), and that digital technology fundamentally redefines citizenship (Dahlgren, 2003; 2009), OPSBs' idea of digital citizenship predominately facilitates personally responsible citizens who maintain the social norm. This narrow focus is a failure with regards to democratic schools' purpose to create deliberative and critical citizens (Barber, 1992). Indeed, excluding the civic attribute of digital citizenship indicates how, "education can function either to create passive, risk-free citizens or to create a politicized citizenry educated to fight for various forms of public life informed by a concern for justice, happiness, and equality" (Giroux \& McLaren, 1986, p. 224). My analysis reflects that OPSBs generate understanding of digital citizenship towards the former function. OPSBs' reliance on personally responsible citizenship aspects is both practical and important. However, solely relying on this understanding ignores the full potential of youth digital technology use as well as digital technology's capacity to foster civic engagement.

\section{Limitations}

While the sample used in this study was considered robust as it includes a majority of the student population in Ontario, different results may have been reached if a larger school board sample was used. Furthermore, it is possible that different results would be available had French school boards been included in the sample as well. Future research in this area should employ a wider sample with specific inclusion of French school boards. Lastly, a more robust study should compare OPSB digital citizenship documents with the Technological Education curricula to extract implied attributes of digital citizenship. Despite the fact that these curricula do not 
mention digital citizenship, it is possible that such ideas of what a digital citizen is can be examined in these documents.

\section{Conclusion}

OPSBs' current conceptualization of digital citizenship is constrained by a narrow understanding of citizenship and should be developed to further reflect the influence of digital technology on civic engagement. Digital citizenship education in Ontario perpetuates an ideal of personally responsible digital citizenship, while excluding participatory and justice-oriented notions of citizenship. This insight is important to reflect upon as OPSBs' conceptualization implies a specific relationship between digital technology and ideas of citizenship. That is, in understanding how OPSBs construct digital citizenship, technology by proxy is perceived as a tool to be used within responsible and ethical means, and not as a mechanism for social inquiry and communication. While Giroux and McLaren (1986) discuss schools as generating either passive citizens or politicized citizens, my results indicate that the underlying framework to understand digital citizenship is overwhelmingly depoliticized. As such, OPSBs' characterization of digital citizenship very much accords to favouring passive digital citizens. This is done through describing digital citizenship as proper behaviour. In this attribute of digital citizenship, the behavioural aspects of digital citizens are: safe, responsible, respectful, and legal. Of course, my critique of this approach is not to antithetically suggest that digital citizens should be precarious, irresponsible, disrespectful, and criminal. Rather, in considering the research demonstrating a connection between digital technology and civic engagement, OPSBs severely miss the opportunity to redevelop ideas of citizenship connected to participation and social justice. There is no mention of using digital technology for social inquiry or civic engagement, nor how technology is a mechanism for communicating such perspectives. However, with the behavioural attributes of digital citizenship endorsed throughout the examined OPSBs, this paper hopes to influence further considerations for developing the idea of digital citizenship. The understanding of the personally responsible digital citizen is clearly established, however, the

next step is to consider how digital citizenship might be infused with notions of participatory and justice-oriented citizenship. 


\section{References}

Alberta Education. (2012). Digital citizenship policy development guide. Edmonton, AB: Alberta Ministry of Education.

Abowitz, K. K., \& Harnish, J. (2006). Contemporary discourses of citizenship. Review of Educational Research, 76(4), 653-690. doi/10.3102/00346543076004653

Bakardjieva, M., Svensson, J., \& Skoric, M. M. (2012). Digital citizenship and activism: Questions of power and participation online. eJournal of eDemocracy and Open Government, 4(1), i-v. doi:10.29379/jedem.v4i1.113

Barber, B. R. (1992). An aristocracy for everyone: The politics of education and the future of America. New York, NY: Ballantine Books.

Baumgartner, J. C., \& Morris, J. S. (2010). MyFaceTube politics: Social networking Web sites and political engagement of young adults. Social Science Computer Review, 28(1), 24 44. doi:10.1177/0894439309334325

Bennett, W. L., Wells, C., \& Rank A. (2009). Young citizens and civic learning: Two paradigms of citizenship in the digital age. Citizenship Studies, 13(2), 105-120.

doi:10.1080/13621020902731116

Berman-Dry, A. (2013). Making it personal: A new approach to teaching digital citizenship. Learning \& Leading with Technology, 41(1), 24-26. http://www.iste.org/

Charmaz, K. (2006)._Constructing grounded theory: A practical guide through qualitative analysis. Thousand Oaks, CA: Sage Publishers.

Choi, M. (2016). A concept analysis of digital citizenship for democratic citizenship education in the Internet age. Theory \& Research in Social Education, 44(4), 565-607. doi:10.1080/00933104.2016.1210549

Choi, M., Cristol, D., \& Gimbert, B. (2018). Teachers as digital citizens: The influence of individual backgrounds, Internet use, and psychological characteristics on teachers' levels of digital citizenship. Computers \& Education, 121, 143-161.

doi:10.1016/j.compedu.2018.03.005

Choi, M., Glassman, M., \& Cristol, D. (2017). What it means to be a citizen in the Internet age: Development of a reliable and valid digital citizenship scale. Computers \& Education, 107, 100-112. doi:10.1016/j.compedu.2017.01.002

Coleman, S. (2013). How voters feel. Cambridge, MA: Cambridge University Press.

Couldry, N., Stephansen, H., Fotopoulou, A., MacDonald, R., Clark, W., \& Dickens, L. (2014). Digital citizenship? Narrative exchange and the changing terms of civic culture. Citizenship Studies, 18(6), 615-629. doi:10.1080/13621025.2013.865903

Couros, A., \& Hildebrandt, K. (2015). Digital citizenship education in Saskatchewan schools: A policy planning guide for school divisions and schools to implement digital citizenship education from kindergarten to Grade 12. Government of Saskatchewan, Ministry of Education. https://pubsaskdev.blob.core.windows.net/pubsask-prod/83322/83322DC_Guide_-_ENGLISH_2.pdf 
Curriculum Services Canada. (2017). Chronicling the impact of $21^{\text {st }}$ century innovation research initiative on students, teachers, and system: Local innovation research projects in Ontario. Oakville, ON: Council of Ontario Directors of Education.

Dahlgren, P. (2003). Reconfiguring civic culture in the new media milieu. In J. Corner \& D. Pels (Eds.), Media and restyling of politics, (pp. 151-170). London, UK: Sage Publishers.

Dahlgren, P. (2009). Media and political engagement: Citizens, communication, and democracy. Cambridge, UK: Cambridge University Press.

Foley, A. S., \& Davis, A. H. (2017). A guide to concept analysis. Clinical Nurse Specialist: The Journal for Advanced Nursing Practice, 31(2), 70-73. doi:10.1097/NUR.0000000000000277

Fournier-Sylvester, N. (2013). From the chatroom to the voting booth: The potential of using online discussion forums to develop civic skills online. Citizenship Education Research Network (CERN) Collection, 2013, 34-45.

Giroux, H. A., \& McLaren, P. (1986). Teacher education and the politics of engagement: The case for democratic schooling. Harvard Educational Review, 56(3), 213-238. https://www.hepg.org/

Gleason, B., \& Gillern, S. (2018). Digital citizenship with social media: Participatory practices of teaching and learning in secondary education. Educational Technology \& Society, 21(1), 200-212. https://www.j-ets.net/

Hintz, A., Dencik, L., \& Wahl-Jorgensen, K. (2019). Digital citizenship in a datafied society. Medford, MA: Polity Press.

Hobbs, R., Donnelly, K., Friesem, J., \& Moen, M. (2013). Learning to engage: How positive attitudes about the news, media literacy, and video production contribute to adolescent civic engagement. Educational Media International, 50(4), 231-246. doi:10.1080/09523987.2013.862364

Hollandsworth, R., Dowdy, L., \& Donovon, J. (2011). Digital citizenship in K-12: It takes a village. TechTrends: Linking Research and Practice to Improve Learning, 55(4), 37-44. doi:10.1007/s11528-011-0510-z

International Society for Technology in Education. (2016). ISTE Standards: Students. https://id.iste.org/docs/pdfs/20-14_ISTE_Standards-S_PDF.pdf

Isman, A., \& Gungoren, O. C. (2014). Digital citizenship. The Turkish Online Journal of Educational Technology, 13(1), 73-77. http://www.tojet.net/

James, C. (2014). Disconnected: Youth, new media, and the ethics gap. Cambridge, MA: The MIT Press.

Jones, L. M., \& Mitchell, K. J. (2016). Defining and measuring youth digital citizenship. New Media \& Society, 18(9), 2063-2079. doi:10.1177/1461444815577797

Kahne, J., \& Bowyer, B. (2017). Educating for democracy in a partisan age: Confronting the challenges of motivated reasoning and misinformation. American Educational Research Journal, 54(1), 3-34. doi:10.3102/0002831216679817 
Kahne, J., Hodgin, E., \& Eidman-Aadahl, E. (2016). Redesigning civic education for the digital age: Participatory politics and the pursuit of democratic engagement. Theory and Research in Social Education, 44(1), 1-35. doi:10.1080/00933104.2015.1132646

Kahne, J., Lee, N. J., \& Feezell, J. T. (2013). The civic and political significance of online participatory cultures among youth transitioning to adulthood. Journal of Information Technology \& Politics, 10(1), 1-20. doi:10.1080/19331681.2012.701109

Kara, N. (2018). Understanding university students' thoughts and practices about digital citizenship: A mixed methods study. International Forum of Educational Technology \& Society, 21(1), 172-185. https://www.j-ets.net/ETS/index.html

Kim, M., \& Choi, D. (2018). Development of youth digital citizenship scale and implication for educational setting. Educational Technology \& Society, 21(1), 155-171. https://www.jets.net/

Kim, Y., Russo, S., \& Amná, E. (2017). The longitudinal relation between online and offline political participation among youth at two different developmental stages. New Media \& Society, 19(6), 899-917. doi:10.1177/1461444815624181

Kirkman, J. (2014). Building a culture of trust: Trust in the use of educational technology. Australian Educational Computing, 29(1), 1-10. http://journal.acce.edu.au/

Krutka, D. G., \& Carpenter, J. P. (2017). Digital citizenship in the curriculum. Educational Leadership, 75(3), 50-55. http://www.ascd.org/Default.aspx

Lee, N. J., Shah, D. V., \& McLeod, J. M. (2012). Processes of political socialization: A communication mediation approach to youth civic engagement. Communication Research, 40, 1-29. doi:10.1177/0093650212436712

Linneberg, M. S., \& Korsgaard, S. (2019). Coding qualitative data: A synthesis guiding the novice. Qualitative Research Journal, 19(3), 259-270. doi:10.1108/QRJ-12-2018-0012

Manning, N., \& Edwards, K. (2014). Why has civic education failed to increase young people's political participation? Sociological Research Online, 19(1), 1-12. doi:10.5153/sro.3206

Martin, F., Wang, C., Petty, T., Wang, W., \& Wilkins, P. (2018). Middle school students' social media use. Educational Technology \& Society, 21(1), 213-224. https:/www.j-ets.net/

Mattson, K., \& Curran, M. B. (2017). Digital citizenship education: Moving beyond personal responsibility. In B. S. de Abreu, P. Mihailids, A. Y. L. Lee, J. Melki, \& J. McDougall (Eds.), International handbook of media literacy education (pp. 144-155). New York, NY: Routledge.

McGillivray, D., McPherson, G., Jones, J., \& McCandlish, A. (2016). Young people, digital media making and critical digital citizenship. Leisure Studies, 35(6), 724-738. doi:10.1080/02614367.2015.1062041

Mesch, G. S. (2018). Parent-child connections on social networking sites and cyberbullying. Youth \& Society, 50(8), 1145-1162. doi:10.1177/0044118X16659685

Middaugh, E., \& Kahne, J. (2009). Online localities: Implications for democracy and education. Yearbook of the National Society for the Study of Education, 108(1), 192-218. 
Mossberger, K., Tolbert, C. J., \& McNeal, R. S. (2008). Digital citizenship: The Internet, society, and participation. Cambridge, MA: The MIT Press.

Nebel, M., Jamison, B., \& Bennett, L. (2009). Students as digital citizens on Web 2.0. Social Studies and the Young Learner, 21(4), 5-7.

https://www.socialstudies.org/publications/ssyl

Ohler, J. (2012). Digital citizenship means character education for the digital age. Kappa Delta Pie Record, 47(1), 25-27. https://www.kdp.org/publications/kdprecord/index.php

Ontario Ministry of Education. (2016). $21^{\text {st }}$ century competencies: Foundation document for discussion. Toronto, ON: Queen's Printer for Ontario.

http://www.edugains.ca/resources21CL/About21stCentury/21CL_21stCenturyCompetenc ies.pdf

Ontario Ministry of Education (OME). (2018a). The provincial code of conduct and school board codes of conduct. Toronto, ON: Queen's Printer for Ontario.

https://www.education-leadership-

ontario.ca/application/files/2114/9876/0970/PolicyProgram_Memorandum_No._128_The

_Provincial_Code_of_Conduct_and_School_Board_Codes_of_Conduct.pdf

Ontario Ministry of Education (OME). (2018b). Ontario public schools enrolment. Toronto, ON: Queen's Printer for Ontario.

Ontario Ministry of Education (OME). (2019a). Education that works for you Modernizing classrooms. Newsroom. Toronto, ON: Queen's Printer for Ontario.

Ontario Ministry of Education (OME). (2019b). School information and student demographics. Toronto, ON: Queen's Printer for Ontario.

Panke, S., \& Stephens, J. (2018). Beyond the echo chamber: Pedagogical tools for civic engagement discourse and reflection. International Forum of Educational Technology \& Society, 21(1), 248-263. https://www.j-ets.net/

Pasek, J., More, E., \& Romer, D. (2009). Realizing the social Internet?: Online social networking meets offline civic engagement. Journal of Information Technology \& Politics, 6(3-4), 197-215. doi:10.1080/19331680902996403

Ribble, M. (2012). Digital citizenship for educational change. Kappa Delta Pi Record, 48(4), 148-151. https://www.kdp.org/publications/kdprecord/index.php

Ribble, M. (2015). Digital citizenship in schools: Nine elements all students should know. Washington, D.C.: International Society for Technology in Education.

Ribble, M., Bailey, G., \& Ross, T. (2004). Digital citizenship: Addressing appropriate technology behavior. Learning \& Leading with Technology, 32(1), 6-11. http://www.learningandleading-digital.com/learningandleading/Store.action

Richards, R. (2010). Digital citizenship and Web 2.0 tools. MERLOT Journal of Online Learning and Teaching, 6(2), 516-522. https://jolt.merlot.org/

Ritzer, G., \& Jurgenson, N. (2010). Production, consumption, prosumption: The nature of capitalism in the age of the digital 'prosumer.' Journal of Consumer Culture, 10, 13-36. doi:10.1177/1469540509354673 
Robb, M., \& Shellenbarger, T. (2013). Promoting digital citizenship and academic integrity in technology classrooms. The Teaching Professor, 27(8), 10-13.

Rodgers, B, L. (1989). Concepts, analysis and the development of nursing knowledge: The evolutionary cycle. Journal of Advanced Nursing, 14(4), 330-335. doi:10.1111/j.13652648.1989.tb03420.x

Saldaña, J. (2013). The coding manual for qualitative researchers. Washington, DC: Sage Publishers.

Statistics Canada. (2018). A portrait of Canadian youth. Ottawa, ON: Statistics Canada. https://www150.statcan.gc.ca/n1/en/pub/11-631-x/11-631-x2018001eng.pdf?st=bK_s_y2d

Toulmin, S. (1972). Human understanding. Princeton, NJ: Princeton University Press.

Turow, J. (2015). The daily you: How the new advertising industry is defining your identity and your worth. New Haven, CT: Yale University Press.

Walker, L. O., \& Avant, K. C. (2011). Strategies for theory construction in nursing. Upper Saddle River, NJ: Pearson.

Westheimer, J., \& Kahne, J. (2004). What kind of citizen? The politics of educating for democracy. American Educational Research Journal, 41(2), 237-269. doi:10.3102/00028312041002237

Wineburg, S., \& Reisman, A. (2015). Disciplinary literacy in history: A toolkit for digital citizenship. Journal of Adolescent \& Adult Literacy, 58(8), 636-639. doi:10.1002/jaal.410

Winn, M. R. (2012). Promote digital citizenship through school-based networking. Learning \& Leading with Technology, 39(4), 10-13. http://www.learningandleadingdigital.com/learningandleading/Store.action

Wojcieszak, M., \& Mutz, D. (2009). Online groups and political discourse: Do online discussion spaces facilitate exposure to political disagreement? Journal of Communication, 59(1), 40-56. doi:10.1111/j.1460-2466.2008.01403.x

Young, D. (2014). A $21^{\text {st }}$-century model for teaching digital citizenship. Educational Horizons, 92, 9-12. https://journals.sagepub.com/home/ehm 


\section{Appendix A: Digital Citizenship Documents and Associated OPSB}

1. Toronto District School Board. (2007). TDSB ICT standards: Digital learning for kindergarten to grade 12.

2. Peel District School Board. (2013). Policies and regulations: Digital citizenship.

3. Thames Valley District School Board. (2019). Digital citizenship.

4. Ottawa-Carleton District School Board. (2012). Enabling a culture of access and mobility: Planning for technology usage in the OCDSB.

5. Durham District School Board. (n.d.) Digital citizenship.

6. Waterloo Region District School Board. (n.d.) Digital citizenship.

7. Hamilton-Wentworth District School Board. (2019). Digital citizenship at HWDSB.

8. Halton District School Board. (n.d.). HDSB digital citizenship overview.

9. District School Board of Niagara. (n.d.). Information technology digital citizenship agreement: Intermediate and Senior Students.

10. Simcoe Country DSB. (2017). Information and computing technology Appropriate use guidelines for students. 